\title{
Dariusz Kubinowski, Urszula Lewartowicz (red.): Kompetencje kluczowe animatorów kultury i ich kształcenie. Toruń 2020, Wydawnictwo Adam Marszałek,
} ss. 288 ISBN: 978-83-8180-397-7

Problematyka kształcenia animatorów kultury była podejmowana wielokrotnie przez Ogólnopolską Federację Ośrodków Kształcenia Animatorów i Menedżerów Kultury, jak i ostatnio w ramach Grupy Studyjnej ds. Animacji Kultury Sekcji Pedagogiki Kultury i Edukacji Międzykulturowej przy Komitecie Nauk Pedagogicznych Polskiej Akademii Nauk, na co wskazują w Stowie wstępnym redaktorzy naukowi monografii Dariusz Kubinowski ${ }^{1}$ i Urszula Lewartowicz ${ }^{2}$ (2020, ss. 6-7).

Kompetencje animatorów kultury są przedmiotem wielu badań, a także planowanego w 2020 roku sympozjum NieKongres Animatorów Kultury, jednak ze względu na pandemię COVID-19 zostało przeniesione na rok 2021. Inicjatorzy i organizatorzy zarazem tego wydarzenia w ramach współpracy dwóch katedr uniwersyteckich: Katedry Pedagogiki Ogólnej, Dydaktyki i Studiów Kulturowych Uniwersytetu Szczecińskiego i Katedry Pedagogiki Kultury Uniwersytetu Marii Curie-Skłodowskiej w Lublinie, przygotowali tę

1 Prof. dr hab. Dariusz Kubinowski, profesor w Katedrze Pedagogiki Ogólnej, Dydaktyki i Studiów Kulturowych Uniwersytetu Szczecińskiego, wiceprzewodniczący Sekcji Pedagogiki Kultury i Edukacji Międzykulturowej przy Komitecie Nauk Pedagogicznych Polskiej Akademii Nauk, członek International Council for Traditional Music - Study Group on Ethnochoreology (UNESCO), koordynator krajowy Transdyscyplinarnej Sieci Badaczy Jakościowych, wiceprezes Polskiego Forum Choreologicznego, nauczyciel akademicki, animator kultury.

2 Dr Urszula Lewartowicz, adiunktka Katedry Pedagogiki Kultury Uniwersytetu Marii Curie-Skłodowskiej, poetka, satyryczka, instruktorka i reżyserka teatralna, autorka scenariuszy i książek dla dzieci, pedagożka, nauczycielka akademicka, animatorka kultury. 
publikację, do której tworzenia rozdziałów zaproszono znawców problematyki o bogatym dorobku naukowym w wybranym obszarze kompetencji.

Rafał Koziński ${ }^{3}$ z uznaniem pisze o monografii jako dyrektor artystyczno-programowy Centrum Kultury w Lublinie, które wsparło wydanie tej książki „z przekonaniem, że wiedza teoretyczna staje się fundamentem działań praktycznych dla różnorodnych animatorów" (Kubinowski i Lewartowicz 2020, okładka).

Praca składa się z dwóch części: ogólnej i szczegółowej. CZĘŚĆ OGÓLNĄ Kompetencje - kształcenie - animacja kultury: dookreślenie zakresów tematycznych i przyjęta perspektywa tworzą 3 rozdziały. Maria CzerepaniakWalczak w pierwszym rozdziale Kompetencja - kompetencje: definiowanie pojęcia zwraca uwagę na wieloznaczność rozumienia kompetencji, a także na różne kryteria ich klasyfikowania, jak: zasięg ujawniania, stopień ogólności czy rola w generowaniu określonych zachowań osoby (2020, ss. 11-21). Tekst ten porządkuje rozumienie kompetencji i jak podkreśla autorka, „wyuczalność i dynamika kompetencji odnosi się zarówno do podmiotowych właściwości animatora/animatorki oraz do ich kondycji w środowisku jego/ jej działania. Oznacza to, że swoimi kompetencjami animatorzy/animatorki kultury mają szansę wyzwalać kształtowanie i aktualizowanie kompetencji uczestników sytuacji i zdarzeń w środowisku animacji” (Czerepaniak-Walczak, 2020, ss. 19-20).

W kolejnym rozdziale Kształcenie animatorów w perspektywie krytycznej pedagogiki kultury Dariusz Kubinowski zwraca uwagę na potrzebę ciągłego (samo)kształcenia animatorów kultury, z czego wielu doświadczyło szczególnie od początku pandemii COVID-19. „Emergentny charakter tego kształcenia wynika z bieżących przemian kulturowych, społecznych, edukacyjnych, ekonomicznych itd., do których animator musi być z wyprzedzeniem przygotowany, aby mógł efektywnie realizować pedagogiczną misję działalności animacyjnej" (2020a, s. 23). Autor podkreśla znaczenie: triady kultura - kształcenie - osobowość w XXI wieku jako wspólnego obszaru studiów i badań pedagogów kultury i pedagogów krytycznych (Kubinowski, 2020a, s. 25) oraz animatora kultury jako krytycznego pedagoga publicznego (Kubinowski, 2020a, ss. 26-27). Prezentuje dotychczasowy stan badań w obszarze kompetencji animatorów kultury, jak i praktyki kształcenia formalnego w ośrodkach akademickich, pozaformalnego koordynowanego przez Naro-

3 Absolwent pierwszego rocznika kształcenia animatorów kultury w Polsce kierunku animator i menedżer kultury na UMCS, kreator kultury, artysta miasta Lublin. 
M. Mikut $\$$ Dariusz KubinowsKi, URsZUla Lewartowicz (RED.): KompetenCJE 431

dowe Centrum Kultury i nieformalnego w toku pracy animatorów kultury i współpracy przy różnych okazjach (Kubinowski, 2020a, ss. 29-31).

W ostatnim rozdziale tej części zatytułowanym Istota animacji kultury $i$ swoistość roli animatora kultury Urszula Lewartowicz wymienia i syntetycznie charakteryzuje wielość i różnorodność ról przypisywanych animatorowi (2020, ss. 32-41), ze szczególnym uwypukleniem jego społecznej roli, która jest złożona i wielowymiarowa, uwikłana w dylematy (2020, s. 40). „Dylematyczność społecznej roli animatora kultury dotyczy różnych jej wymiarów, przyjmując postać takich opozycji, jak: profesjonalista/hobbysta (dylemat związany z kształceniem kompetencji animatora), lider/jeden z nas (dylemat dotyczący pozycji animatora w gupie), „jednacz”/strażnik podmiotowości (dylemat wynikający z dwoistości animacji, która służyć ma celom jednostkowym i grupowym), odkrywca/sublimator (dylemat natury ideowej związany z postmodernistycznymi i humanistycznymi źródłami animacji), idealista/ pragmatyk (dylemat dotyczący misji działań animacyjnych w dobie gospodarki rynkowej)" (Kubinowski, Lewartowicz, 2018, ss. 114-120).

CZĘŚĆ OGÓLNA bez wątpienia jest bardzo dobrze przemyślana i wprowadza w pewien porządek rozumienia kompetencji i pełnionych ról animatorów kultury, jak i potrzebę ustawicznego (samo)kształcenia i aktualizowania kompetencji. Autorzy tych rozdziałów z dużą wrażliwością i profesjonalizmem prezentują syntetycznie pracę animatorów/animatorek kultury, ukazując nieoczywistość i wielowymiarowość ich ról oraz zmienność i dynamikę w perspektywie krytycznej pedagogiki kultury.

CZĘŚĆ SZCZEGÓŁOWA Wybrane kompetencje kluczowe animatorów kultury oraz ich formalne, pozaformalne i nieformalne kształcenie jest zdecydowanie obszerniejsza, którą tworzy 17 rozdziałów - każdy poświęcony innej kompetencji kluczowej animatorów kultury i napisany przez innego autora - reprezentanta/reprezentantki ośrodka akademickiego prowadzącego kształcenie animatorów kultury w Polsce. Poszczególne rozdziały poświęcone są następującym kompetencjom: emancypacyjność, kreatywność, międzykulturowość, alternatywność, dialogiczność, metodyczność, aksjologiczna ideowość, krytyczna apolityczność, empatia, inkluzyjność, multikomunikatywność, wrażliwość estetyczna, ekologiczność, performatywność, transgresyjność, transsynergiczność, uważność.

Autorzy nie ujawniają, według jakiego kryterium dokonali wyboru właśnie takich kompetencji, choć wymieniają opracowania naukowe stanowiące podstawę do dyskusji nad kluczowymi kompetencjami animatorów kultury (Kubinowski i Lewartowicz, 2020, s. 5). 
Na podkreślenie zasługuje niestosowana wcześniej i nieistniejąca w leksykalnych opracowaniach oryginalność nazw niektórych kompetencji poprzez dodanie do trzonu słowa przyrostka „-ość” (Stownik języka polskiego). Takie określenia zastosowano w nazwach niektórych kompetencji, jak: alternatywność, emancypacyjność, multikomunikatywność, międzykulturowość, transgresyjność. Ten sufiks umieszczony za trzonem pojęcia wskazuje na neutralną cechę kogoś lub czegoś, pozbawione jest oceniania (Sowińska, 2018).

W przypadku niektórych nazw kompetencji to neologizmy, jak w pojęciu transsynergiczności jako połączenia synergii, synkretyzmu i przedrostka „trans-.” Autor rozdziału Transsynergiczność proponuje, aby ta kompetencja „oznaczała płynną, emergentną, nieustannie zmienną synergię animacji kultury, w jej założeniach antropologiczno-pedagogicznych, z wszelkimi różnymi dziedzinami praktyk społecznych, kulturowych, edukacyjnych, gospodarczych, religijnych itd. służących dobru człowieka/ludzi i kreowaniu lepszego świata w celu osiągnięcia większej efektywności wspólnych działań zmierzających do analogicznych celów" (Kubinowski, 2020b, s. 240). Zamysłem redaktorów tej monografii było zwrócenie uwagi na pojemność znaczeniową oraz nieoczywistość i emergentną naturę tych kompetencji.

Warto także uwypuklić szczególny wymiar czasu tworzenia poszczególnych treści rozdziałów. „Teksty te powstawały bezpośrednio przed pandemią COVID-19 w Polsce i na świecie bądź w trakcie początkowych miesięcy jej rozwijania się, co zainspirowało niektórych autorów do pierwszych prób uwzględnienia wpływu przymusowej izolacji społecznej spowodowanej sytuacją epidemiczną na funkcjonowanie animatorów kultury, w szczególności w kontekście wyzwania działalności e-animacyjnej" (Kubinowski i Lewartowicz, 2020, s.7).

Wszystkie rozdziały poświęcone kompetencjom zawierają podobne elementy, to jest: źródłosłów, kompetencja w kontekście pracy animatora kultury, możliwości rozwijania kompetencji w ramach edukacji formalnej, pozaformalnej i nieformalnej, jednak, co jest ogromnym walorem tej pracy, każdy $\mathrm{z}$ autorów prezentuje różnorodne odniesienia tych kompetencji do działalności animatorów kultury, niektórzy odnieśli się także do aktualnych wydarzeń wywołanych pandemią COVID-19 w czasie tworzenia danego rozdziału. Jak bardzo dana kompetencja ewoluuje i zbieżna jest z tym, co „tu i teraz”, świetnie oddaje Aneta Makowska, odwołując się do Performatyki R. Schechner (2006). „Pisząc ten tekst, uczestniczę w performansie. Performujemy: odtwarzamy zachowania (...), odwołując się do znanych doświadczeń i scenariuszy, np. wobec widma zamknięcia w domach, robimy zapasy żywno- 
M. Mikut $\nrightarrow$ Dariusz Kubinowski, Urszula Lewartowicz (ReD.): KompetenCJE 433

ści. Ogrywamy role: np. dobrych obywateli. Nie chodzimy do sklepów zbyt często i posłusznie czekamy przed urzędem pocztowym w 1,5-metrowych odstępach. Część z nich jest zainscenizowana (jak nakładka na zdjęciu profilowym FB\#zostań w domu, założona w restauracji, tuż przed zamknięciem lokali), część z nich prawie w ogóle nie wydaje się nam być grą, która jest przygotowana dla widzów (jak troskliwy telefon do rodziców: "proszę, nie idźcie dziś do kościoła") (...) Swoje role odgrywają także: laboratoria, techniki wizualne i zdjęcia 3D ukazujące „koronę” wirusa, radio i media, które stoją za przygotowanymi informacjami, grupa Facebookowa „Szczecinianki”, organizująca się w celu szycia maseczek ochronnych dla szpitali, lęk przed chorobą, testy diagnostyczne, telefon, komputer, „Inny-Obcy” (...). Solidaryzujemy się z trudną sytuacją Włochów (wczoraj szczecińska Filharmonia przybrała kolory włoskiej flagi), laboratoria współpracują na poziomie międzynarodowym, Unia Europejska zamknęła granice, Chiny dzielą się swoimi zasobami, uczymy się, jak dochować kwarantanny dzięki filmikom Włochów, wiedzę i praktyki zapośredniczamy przez media" (Makowska, 2020, ss. 215$-216){ }^{4}$

Warto jednak podkreślić, że wśród opracowań 17 kompetencji znalazły się te, które współcześnie uznawane są za istotne, także w kontekście nieprzewidywalnej przyszłości. „Wielu ekspertów zajmujących się pedagogiką twierdzi, że szkoły powinny przestawić się na uczenie „czterech K” - krytycznego myślenia, komunikacji, kooperacji i kreatywności. (...) Najważniejsza będzie zdolność radzenia sobie ze zmianą, uczenia się nowych rzeczy i zachowania równowagi psychicznej w nieznanych sytuacjach. Aby nadążać za tempem świata w 2050 roku, trzeba będzie nie tylko tworzyć nowe pomysły i produkty, lecz także, a może przede wszystkim, raz po raz tworzyć samego siebie" (Harari, 2018, s. 335). To jest wyzwanie dla szkół wszystkich szczebli, ale także dla kształcenia animatorów kultury.

Zmiana w zmianie to domena współczesności, a jej konsekwencją jest ogromna dynamika w obszarze wiedzy i kompetencji. Ta zmienność zawiera się między innymi w takich kompetencjach, jak: alternatywność, emancypacyjność, performatywność, transgresyjność, transsynergiczność. Komunikacja i kooperacja niezbędna jest dla aksjologicznej ideowości, dialogiczności, empatii, inkluzyjności, metodyczności, międzykulturowości, multikomunikatywności, uważności i wrażliwości estetycznej. Kreatywność w każdej

4 Zastosowałam oryginalną pisownię autorki z pogrubieniami wybranych treści i cudzysłowami, aby oddać istotę przedstawionego performansu. 
profesji jest kluczowa dla generowania rozwiązań problemów wynikających z dynamiki zmian.

Sir Ken Robinson - światowej sławy lider w dziedzinie rozwoju kreatywności, innowacyjności i zasobów ludzkich - podkreśla potrzebę uchwycenia żywiołu. Żywioł jest tam, gdzie talent spotyka się z pasją osobistą (2012). Taki żywioł powinni posiadać animatorzy kultury, którzy potrzebują „płomienia”, by ożywić swoje działanie i innych, a do tego potrzeba transgresyjności. „Transgresyjność jako kompetencja animatora kultury jest szczególnie istotna $\mathrm{w}$ jego pracy z osobami czy środowiskami społecznymi niezaangażowanymi czy też zaniedbanymi kulturalnie, nieświadomymi potrzeb kulturalnych" (Mikut, 2020, s. 231). Animator kultury jest swoistym zaczynem pod pewne zmiany w środowisku, w którym działa. Doświadczenie światowej pandemii wywołanej wirusem SARS-CoV-2 zainicjowało nową jakość działań animatorów kultury, zwłaszcza po zamknięciu instytucji kultury i przeniesienia ich do sieci. Wiele osób związanych z kulturą przeszło swoistą transgresję, ale doświadczyło jej także wiele osób, które nie uczestniczyły przed pandemią w aktywności kulturalnej. W ramach działań \#Zostań $w$ domu wiele instytucji kultury, jak i indywidualnych osób uruchomiło szereg aktywności związanych z animacją kulturalną różnych grup społecznych w sieci. „(..) niektórzy dokonywali swoistych inicjacji do świata kultury za sprawą poczucia, że uczestniczą w słusznej sprawie (np. ku pokrzepieniu serc medyków czy w ramach akcji wsparcia osób znajdujących się w trudnej sytuacji z powodu izolacji społecznej)" (Mikut, 2020, ss. 237-238).

Pandemia bez wątpienia ujawiła ogromną dynamikę zmian w wymiarze globalnym. Dzieci rozpoczynające w tym roku edukację szkolną prawdopodobnie na emeryturę przejdą najszybciej w 2081 roku. Jaka będzie przyszłość? Tego nikt nie wie, jednak istotne jest uświadomienie sobie, że dynamika zmian będzie coraz większa. Zdaniem Kena Robinsona ,jedyny sposób, by przygotować się na przyszłość, to dać z siebie wszystko, zakładając, że dzięki temu staniemy się elastyczni i produktywni, jak to tylko możliwe" (Robinson, 2012, s. 29). Z całą pewnością lista kompetencji scharakteryzowanych w monografii zbiorowej pod redakcją Dariusza Kubinowskiego i Urszuli Lewartowicz (2020) daje taką szansę.

Komu dedykowana jest ta monografia zbiorowa? Redaktorzy tej książki podkreślają, że: „Wszystkim Animatorom Kultury, pracownikom instytucji i organizacji działalności kulturalnej, studentom kierunków i specjalności z nią związanych, badaczom kultury, wykładowcom, menedżerom, miłośnikom kultury" (Kubinowski i Lewartowicz, 2020, s. 6). Ja osobiście polecam ją 
M. Mikut $₫$ Dariusz Kubinowski, Urszula Lewartowicz (ReD.): KompetenCJE 435

wszystkim, którzy są zaangażowani w sprawy społeczne oraz własny rozwój i którzy współpracują z Innymi w szerokim tego słowa znaczeniu.

\section{Bibliografia}

Czerepaniak-Walczak, M. 2020. Kompetencja - kompetencje: definiowanie pojęcia. W: Kubinowski, D. i Lewartowicz, U. red. Kompetencje kluczowe animatorów kultury i ich kształcenie. Toruń: Wydawnictwo Adam Marszałek, ss. 11-21.

Harari, Y.N. 2018. 21 lekcji na XXI wiek. Kraków: Wydawnictwo Literackie. Kubinowski, D. i Lewartowicz, U. 2018. Animacja kultury w perspektywie pedagogicznej. Studia i szkice. Kraków: Oficyna Wydawnicza „Impuls”.

Kubinowski, D. i Lewartowicz, U. red. 2020. Kompetencje kluczowe animatorów kultury i ich kształcenie. Toruń: Wydawnictwo Adam Marszałek.

Kubinowski, D. 2020a. Kształcenie animatorów w perspektywie krytycznej pedagogiki kultury. W: Kubinowski D. i Lewartowicz U. red. Kompetencje kluczowe animatorów kultury i ich kształcenie. Toruń: Wydawnictwo Adam Marszałek, ss. 22-31.

Kubinowski, D. 2020b. Transsynergiczność. W: Kubinowski D. i Lewartowicz U. red. Kompetencje kluczowe animatorów kultury i ich kształcenie. Toruń: Wydawnictwo Adam Marszałek, ss. 239-251.

Makowska, A. 2020. Performatywność. W: Kubinowski, D. i Lewartowicz, U. red. Kompetencje kluczowe animatorów kultury i ich kształcenie. Toruń: Wydawnictwo Adam Marszałek, ss. 213-227.

Mikut, M. 2020. Transgresyjność. W: Kubinowski, D. i Lewartowicz, U. red. Kompetencje kluczowe animatorów kultury i ich kształcenie. Toruń: Wydawnictwo Adam Marszałek, ss. 228-238.

Robinson, K. 2012. Uchwycić żywiot. O tym, jak znalezienie pasji zmienia wszystko. Kraków: Wydawnictwo DAS Polska Jolanta Baj. Oddział w Krakowie Element.

Schechner, R. 2006. Performatyka. Wstęp. Wrocław: Ośrodek Badań Twórczości Jerzego Grotowskiego i Poszukiwań Teatralno-Kulturowych.

Słownik języka polskiego. https://sjp.pwn.pl/slowniki/przyrostek.html (20.05.2021).

Sowińska, D. 2018. Izmy i ości. Danuta Sowińska blog. https://danutasowinska.pl>izmy-i-osci (20.05.2021). 